J. Clin. Chem. Clin. Biochem.

Vol. 25,1987 , pp. $39-43$

(C) 1987 Walter de Gruyter \& Co.

Berlin - New York

\title{
The Analytical Value for Kinin Concentration in Blood Depends on the Antiserum Used in the Bradykinin Radioimmunoassay
}

\author{
By G. Bönner, D. Iwersen
}

Department of Internal Medicine II, University of Cologne, Cologne, F.R.G. and

\section{K. Shimamoto}

Department of Internal Medicine II, Sapporo Medical College Sapporo, Japan

(Received December 17, 1985//March 24/August 13, 1986)

Summary: Recently published blood kinin concentrations are subjèct a wide scatter, due to sampling time and technique. In our study we tested the influence of the used antibradykinin antiserum on the measured kinin concentration in blood. Blood was collected from the anticubital vein by a teflon cannula and inactivated immediately by hydrochloric acid in the syringe. Subsequent extraction was performed using diethylether, $n$ butanol, distilled water and Biorex-70. The blood extract containing the kinins was divided into four samples and measured by four radioimmunoassays using different antibradykinin antibodies. All four assays were performed under standard conditions and at the same time. The resulting kinin values were similar in two assays: $7.4 \pm 2.6 \mathrm{ng} / \mathrm{l}$ and $5.6 \pm 1.3 \mathrm{ng} / \mathrm{l}$. In the two other assays, however, the measured kinin concentrations differed markedly from these values: $127.5 \pm 46.7 \mathrm{ng} / 1$ and $693.0 \pm 85.7 \mathrm{ng} / \mathrm{l}$. These results indicate clearly that the antibody used in the assay can be a major factor determining the range of the recorded kinin concentration.

\section{Introduction}

Werle \& Frey (1) and Rocha e Silva et al. (2) discovered the vasodilating activity of substances they called kallidin and bradykinin, respectively. These peptides are one of the most potent vasodilating agents in man and their concentration is of great interest in many physiological and pathophysiological situations. However, measurement of kinins in blood is not easy, since they are released very rapidly by kallikreins in blood and cleaved immediately by kininases into inactive fragments. Thus, the recently published levels of kinins in blood are spread over a wide range of concentrations from $4.2 \pm 1.1 \mu \mathrm{g} / 1$ (3) to less than $3 \mathrm{ng} / \mathrm{l}$ (4). The technique of blood sampling is a possible reason for this discrepancy, since several authors have observed much higher levels of kinins in plasma samples than in acid-inactivated blood $(4,5)$. In their investigation, the observed difference between kinin concentrations in plasma and in blood was due to the time of sampling, since they observed increasing plasma kinin levels with prolongation of the collecting period (4). But even if the collecting period was shortened to a minimum, and all enzymatic activity was inhibited immediately, different values for kinin were obtained for blood and plasma $(4-6)$. Thus, the question arose of whether other factors influence the measurement of kinins in blood. In the presented study we analysed the same blood sample after acid inactivation and kinin extraction in four assay systems which differed only in the antibradykinin antiserum used.

\section{Materials and Methods}

Antibody

Four antibodies were used in the assay system:

1. antibody $07 \mathrm{a}$ which was produced by immunisation of rabbits with bradykinin coupled to human serum albumin by $1,5-$ difluoro-2,4-dinitrobenzene (7); 
2. antibody $\mathrm{Si}$ which was produced by immunisation of rabbits with bradykinin coupled to edestin by 1-ethyl-3-dimethylaminopropyl-carbodiimide (7);

3. antibody $\mathrm{Hu}$ which was produced by immunisation of rabbits with bradykinin coupled to ovalbumin by toluene-2,4diisocyanate (8);

4. antibody Sh which was produced by immunisation of rabbits with bradykinin coupled to bovine serum albumin by 1-ethyl3-dimethylaminopropyl-carbodiimide (9).

In the assay the working dilution of antibody was

$1: 16000$ for $07 \mathrm{a}$,

$1: 8000$ for $\mathrm{Si}$,

$1: 50000$ for $\mathrm{Hu}$, and

$1: 500000$ for Sh.

\section{Tracer}

The radiolabelled antigen was prepared according to Greenwood \& Hunter as previously published $(10,11)$. [125I-Tyr $\left.{ }^{8}\right]$ bradykinin was used as tracer in the assays with antibody $07 \mathrm{a}, \mathrm{Si}$ and $\mathrm{Hu}$. [125I-Tyr $\left.{ }^{1}\right] \mathrm{kallidin}$ was used as tracer in the assay with antibody Sh for better sensitivity while specifity remained unchanged. Radioactivity added to the test tube was about 8000 counts/min.

\section{Radioimmunoassay}

The radioimmunoassay for determination of bradykinin was performed as previously described (11). In each assay, known control samples were checked for their bradykinin content, in order to test the assay system. Kinins in the blood sample were calculated from the standard curve, only if the corresponding controls were satisfactory.

\section{Extraction}

Peripheral venous blood was obtained from 16 healthy volunteers ( 10 females, 6 males) in sitting position. The technique of blood sampling and kinin extraction was a modified version of that reported by two groups $(12,13)$. A teflon cannula (Viggo ${ }^{\circledR}$ ) was inserted into an antecubital vein and free blood flow was observed. Without strong drawing $10 \mathrm{ml}$ of blood were collected into a syringe containing $30 \mathrm{ml}$ of $1 \mathrm{~mol} / 1 \mathrm{HCl}$. In this way an immediate inactivation of all plasma enzymes was achieved, preventing kinin formation or cleavage. The mixture was added to $50 \mathrm{ml}$ of diethylether, shaken thoroughly, then centrifuged for $15 \mathrm{~min}$ at $2500 \mathrm{~g}$. After centrifugation the upper layer with the lipids and the pellet of blood cells were rejected. The kinins of the remaining fluid were extracted with $50 \mathrm{ml}(5 \times 10 \mathrm{ml})$ of absolute $n$-butanol. After centrifugation for $15 \mathrm{~min}$ at $2500 \mathrm{~g}$ the upper layer was reextracted with $75 \mathrm{ml}(5 \times 15 \mathrm{ml})$ of doubly distilled water. After further centrifugation, the upper layer was rejected and the remaining fluid was evaporated at $60^{\circ} \mathrm{C}$ to dryness. Each sample was redissolved in $60 \mathrm{ml}$ of 0.1 $\mathrm{mol} / \mathrm{l}$ acetic acid ( $\mathrm{pH} \mathrm{4.0)}$. Then this solution was transfered to a Biorex-70 column $(1 \times 1 \mathrm{~cm}$, Biorad) at a rate of $2 \mathrm{ml}$ per $\mathrm{min}$. The kinins retained during the ion exchange chromatography were eluted from the column by $10 \mathrm{ml}$ of $10 \mathrm{~mol} / \mathrm{l}$ acetic acid ( $\mathrm{pH}$ 1.0). Thereafter the acetic acid was evaporated at $60^{\circ} \mathrm{C}$ to dryness. The extracted sample was redissolved in $1 \mathrm{ml}$ of RIA buffer, adjusted to $\mathrm{pH} 7.4$ by $0.1 \mathrm{~mol} / 1 \mathrm{NaOH}$, and divided into four identical portions. Each portion was assayed simultaneously by one of the 4 bradykinin radioimmunoassays described above. The kinin content of the blood sample was calculated with regard to the recovery and the sample dilution. To determine bradykinin recovery in the extraction procedure $500 \mathrm{pg}$ unlabelled bradykinin were added to a second syringe, which was then used to sample a further $10 \mathrm{ml}$ of blood, immediately after the first $10 \mathrm{ml}$ for kinin determination. The extraction procedure of the recovery sample was the same as described for the sample.

\section{Cross-reactivity}

Cross-reactivity of antibodies was tested against highly purified peptides, such as lys-bradykinin, met-lys-bradykinin, ile-serbradykinin, de-arg'-bradykinin, de-phe-arg ${ }^{9}$-bradykinin, dearg-bradykinin. Antibody 07a was additionally tested against the following peptides: arg-pro-pro-gly-phe-ser, pro-pro-glyphe-ser-pro, ser-pro, pro-gly, phe-ser, gly-phe, pro-phe, bradykinin-potentiator $B$ and $C$, substance $P$, neurotensin, eleodoisin, serotonin, leu-encephalin, angiotensin I, II, and III. Furthermore, cross-reactivity of all four antibodies against bovine and human low molecular weight (LMW) kininogen and human serum albumin was studied. The peptides or proteins tested were purchased from Sigma, Bachem, Serva or they were a gift from Dr. Kato. Calculation of cross-reactivity was based on the molar concentration at the $50 \%$ intercept of the dilution curve:

$\%$ cross-reactivity $=\left(\mathrm{BK}_{50 \%} / \mathrm{X}_{50 \%}\right) \cdot 100$

$100 \%$ of cross-reactivity represents an equimolar reactivity of the tested compound $(X)$, when compared with that of bradyki$\operatorname{nin}(\mathrm{BK})$.

\section{Statistical analysis}

Values given represent means \pm SEM. Statistical significance of differences between means was calculated according to $K r u$ skal \& Wallis. Significance was accepted at the $5 \%$ level $(\mathrm{p}<0.05)$.

\section{Results}

Using the extraction method described, it was possible to purify blood kinins for measurement in the bradykinin radioimmunoassay. The extracted kininlike material showed in all four radioimmunoassays the same immunological reactivity as highly purified bradykinin, since the dilution curve of blood extract paralleled the standard curve in all four assays, independently of the antibradykinin antiserum used (fig. 1). The recovery of cold bradykinin added to the sample was $52.9 \pm 4.0 \%$, the coefficient of intraassay variation of bradykinin measurement in blood was $9.8 \%$. When the concentration of kinins was determined under basal conditions in the blood of 16 volunteers, using the different antibodies in the same assay, only two antibodies ( $\mathrm{Sh}$ and $\mathrm{Si}$ ) measured the kinin concentration in the same range, while the two other antibodies $(07 \mathrm{a}$ and $\mathrm{Hu})$ determined quite different values (Sh: $5.6 \pm 1.3 \mathrm{ng} / \mathrm{l}$; Si: $7.4 \pm 2.6$ ng/l; Hu: $127.5 \pm 46.7 \mathrm{ng} / \mathrm{l} ; 07 \mathrm{a}: 693.0 \pm 85.7 \mathrm{ng} / \mathrm{l}$; fig. 2). The difference in kinin concentration determined with the aid of antibodies $\mathrm{Sh}$ and $\mathrm{Si}$ on the one hand, and $07 \mathrm{a}$ on the other hand, was highly significant $(p<0.001)$. The cross-reactivity of the antibodies against other kinins like kallidin (lys-bradykinin), T-kinin (ile-ser-bradykinin) and met-lysbradykinin as well as against bradykinin fragments, low molecular weight kininogen and human serum albumin was nearly the same in all four tested antibodies (tab. 1). Only antiserum Hu showed high 

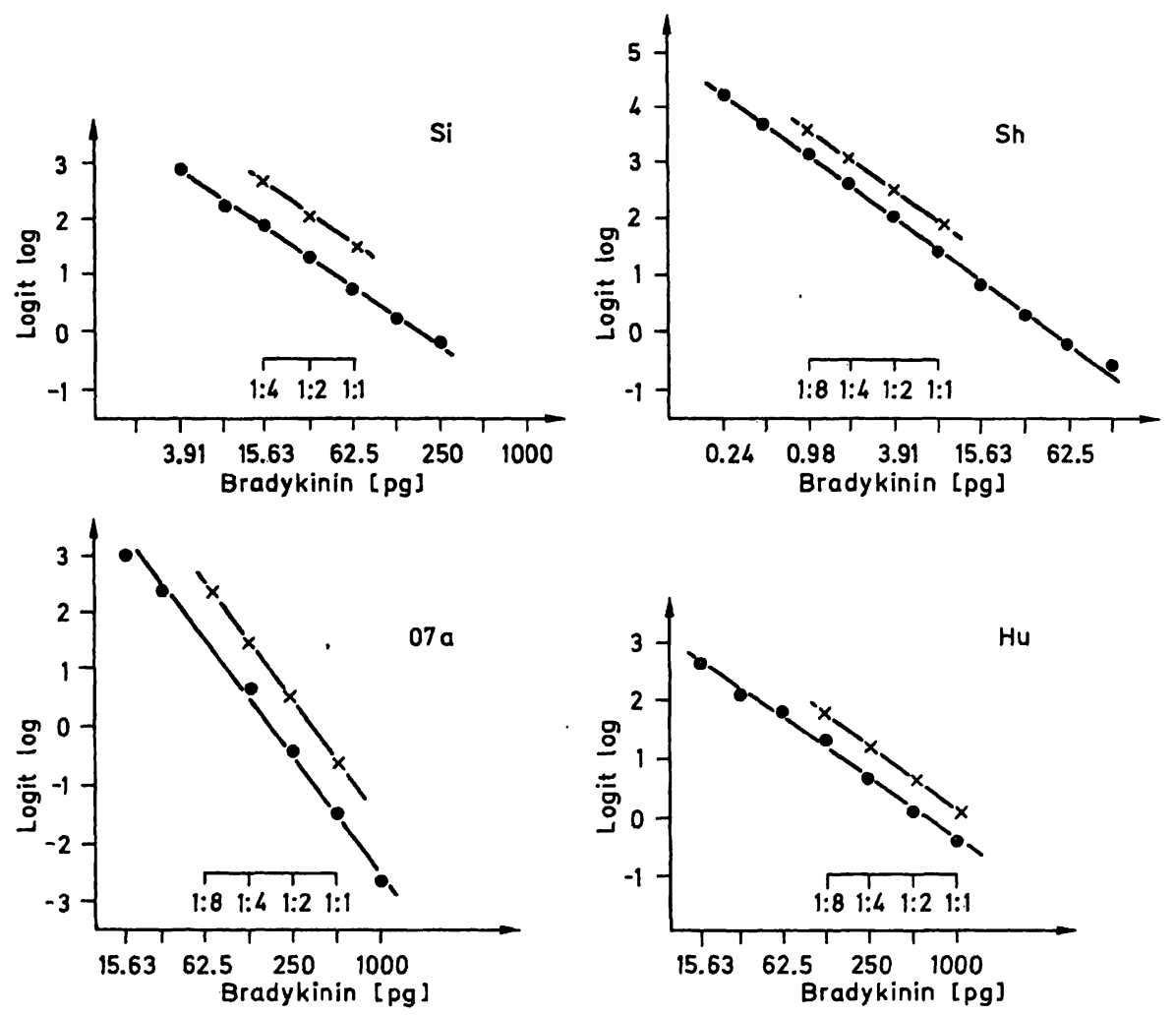

Fig. 1. Standard curve (o) and serial dilution curve of extracted blood sample $(x)$ for the bradykinin radioimmunoassay by four different antibradykinin antisera $(07 \mathrm{a}, \mathrm{Hu}, \mathrm{Sh}, \mathrm{Si})$. The curves are presented as logit-log functions.

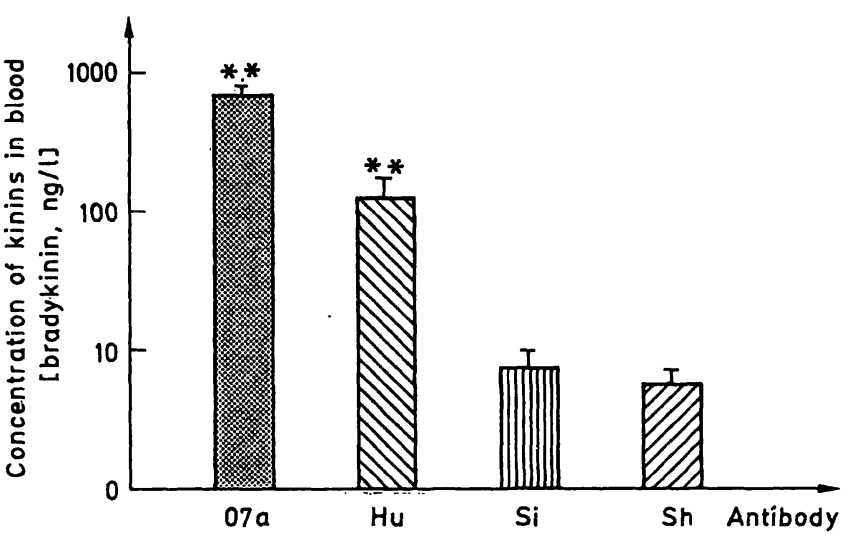

Fig. 2. Concentration of kinins in blood after extraction determined by four different antibradykinin antisera $(07 a$, $\mathrm{Hu}, \mathrm{Si}, \mathrm{Sh}$ ) in the same radioimmunoassay system under identical conditions. The values determined by $07 \mathrm{a}$ and Hu were significantly higher $(* *: p<0001)$ than those determined by $\mathrm{Si}$ and $\mathrm{Sh} . \overline{\mathrm{x}} \pm \mathrm{SEM} ; \mathrm{n}=16$.

cross-reactivity with the bradykinin fragment de-arg ${ }^{1}$ bradykinin and a mild cross-reactivity with bovine and human low molecular weight kininogen. Antibody 07 a cross-reacted only a little with human low molecular weight kininogen, but showed no crossreactivity with any other tested bradykinin fragment or peptide. Antibodies Sh and Si had little crossreactivity with human low molecular weight kininogen, but not with bovine low molecular weight kininogen.
Tab. 1. Comparison of the cross-reactivity of the used four antibradykinin antisera against other kinins, kinin fragments, low molecular weight (LMW) kininogen and human serum albumin.

\begin{tabular}{lcccc}
\hline & \multicolumn{4}{l}{$\begin{array}{l}\text { Cross-reactivity in \% of bradykinin } \\
\text { using antibody }\end{array}$} \\
\cline { 2 - 5 } & $\mathrm{Sh}$ & $\mathrm{Si}$ & $07 \mathrm{a}$ & $\mathrm{Hu}$ \\
\hline Peptide/protein: & & & & \\
Bradykinin (BK) & 100.0 & 100.0 & 100.0 & 100.0 \\
lys-BK & 100.0 & 111.9 & 101.7 & 97.0 \\
met-lys-BK & 100.0 & 77.4 & 85.1 & 42.0 \\
$\begin{array}{l}\text { de-arg-BK } \\
\text { de-phe-arg'-BK }\end{array}$ & 0.02 & 0.02 & $<0.01$ & $<0.01$ \\
de-arg-BK & $<0.01$ & $<0.01$ & $<0.01$ & $<0.01$ \\
LMW-kininogen, & 26.8 & 0.25 & $<0.01$ & 82.0 \\
bovine & $<0.1$ & $<0.01$ & 0.7 & 10.5 \\
$\begin{array}{l}\text { LMW-kininogen, } \\
\text { human }\end{array}$ & 7.5 & 4.2 & 8.2 & 8.2 \\
$\begin{array}{l}\text { Human serum } \\
\text { albumin }\end{array}$ & $<0.01$ & $<0.01$ & $<0.01$ & $<0.01$ \\
\hline
\end{tabular}

\section{Discussion}

Kinins are highly potent peptides involved in many pathological reactions of the organism, such as allergic hypotension, allergic rhinitis, arthritis, pancreatitis, angioneurotic oedema, septic shock, myocardial infarction or acute respiratory distress syndrome after polytraumata or severe injuries $(14,15)$. To elucidate the pathophysiological role of kinins in these diseases it is necessary to measure actual kinin levels in blood. 
Since 1964 many methods of kinin determination in blood have been described $(16-22)$. However, the reported values for kinins in blood range between 4000 and nearly $0 \mathrm{ng} / \mathrm{l}$. The reason for these enormous differences in blood kinin levels are still unclear, in spite of many methodological investigations. First of all it was suggested that the determination of kinins in inactivated plasma samples would present higher kinin levels than in immediately denatured blood, because the kallikreins in plasma probably still liberate kinins until their complete inactivation by inhibitors, which are not added until after blood sampling $(4,5)$. If the enzymatic activity of the plasma sample was completely inactivated immediately at the start of blood sampling by an inhibitor solution in the syringe, no differences between blood and plasma kinin levels were found (13). But promptness in enzyme inactivation during blood sampling is not the only factor influencing the measurement of kinin concentration in blood, since high kinin levels were reported even in immediately inactivated blood samples (6). These findings indicate clearly that there other additional factors exist influencing the basal levels of the measured kinins in either blood or plasma samples.

In our investigation the kinin measurement was performed by four radioimmunoassays simultaneously under identical conditions. There was no difference in the tested samples since the blood sample was divided for the four assays after the last extraction procedure just before the measurement. In all assays the dilution curve of blood extract strongly paralleled the standard curve, indicating that the kinin-like material in blood had an immunoreactivity identical to that of bradykinin in each radioimmunoassay. Thus, it was most surprising that the measured kinin levels were not identical. The kinin concentrations measured by the antibodies $\mathrm{Hu}$ and $\mathrm{Sh}$ were in the same range reported in older studies in a major group of normal man $(6,13)$. Use of the two other antibodies of our laboratory resulted in very high and very low recorded values for the kinin concentration. Thus, our reported results demonstrate for the first time that the kinin level in blood depends at least in part on the antibradykinin antiserum used in the assay.
The reason for this discrepancy in kinin measurement by the four antibodies is not known. However, it can be suggested, that cross-reactivity of the antibodies with fragments of kinins or kininogens probably plays an important role. This could be true for the higher kinin levels determined with antibody $\mathrm{Hu}$, since this antibody has a much higher cross-reactivity againist the de-arg-bradykinin fragment than all other antibodies. If this peptide, which could be released by an aminopeptidase, is present in the blood sample, the normally used extraction procedures are not able to separate this peptide from the intact bradykinin molecule. This might lead to falsely high analytical values for bradykinin. This antibody and antibody $07 \mathrm{a}$ also cross-react with bovine low molecular weight kininogen. However, even if the species (bovine) of the tested kininogen is ignored, the very small crossreactivity with low molecular weight kininogen alone cannot be responsible for the very high recorded levels of kinins in blood, since both kininogens, bovine or human, were completely separated from kinins by the extraction procedure used in our method. But the possibility cannot be excluded that smaller kininogen fragments, carrying the amino acid sequence responsible for an immunological cross-reactivity, are extracted with the kinins, thereby leading to falsely high analytical values for bradykinin.

Even though there is evidence that the analytical value for kinin is affected by the cross-reactivity of the used antibody, we found no cross-reaction of antibody $07 \mathrm{a}$ with all tested $(\mathrm{n}=10)$ bradykinin fragments. Thus, it has to be considered whether an additional unknown factor in blood extract interferes with kinin measurement. The question of the origin of this factor and why it interferes when only certain antibodies are used for the kinin measurement, cannot be answered yet. Further biochemical and immunological investigations are necessary to identify such a factor.

\section{Acknowledgement}

This work was supported by the Deutsche Forschungsgemeinschaft (Bo 618/3). Antibody Hu was a gift of Dr. L. Hulthen, bovine low molecular weight kininogen a gift of Dr. $H$. Kato, and human low molecular weight kininogen a gift of PD Dr. W. Müller-Esterl. We acknowledge the helpful technical assist- ance of Mrs. C. Kapp and Mrs. U. Büchsler.

\section{References}

1. Werle, E., Trautschold, I. \& Leysath, G. (1961) HoppeSeylers Z. Physiol. Chem. 326, 174.

2. Rocha e Silva, M., Beraldo, W. T. \& Rosenfeld, G. (1949) Am. J. Physiol. 156, $261-273$.

3. Verma, P. S., Lorenz, P. E. \& Sander, G. E. (1980) Clin. Chem. 26, 429-432.

4. Nielsen, F., Damkjaer Nielsen, M. \& Giese,'J. (1982) Agents and Actions, Suppl. 9, 227-232.

5. Ando, T., Shimamoto, K., Nakahashi, Y., Nishitani, T., Hosoda, S., Ishida, H., Tanaka, S. \& Iimura, O. (1982)

- Agents and Actions, Suppl. 9, 222-226. 
6. Hulthen, L. U., Lecerof, H. \& Hökfelt, B. (1978) Acta Med. Scand. 203, $411-414$.

7. Stocker, M., Hilgenfeld, U. \& Gross, F. (1979) Experientia $35,1113-1115$.

8. Hulthen, L. U. \& Borge, T. (1976) Scand. J. Clin. Lab. Invest. 36, 833-839.

9. Shimamoto, K., Ando, T., Nakao, T., Tanaka, S., Sakuma, M. \& Miyahara, M. (1978) J. Lab. Clin. Med. 91, 721 728.

10. Greenwood, F. C., Hunter, W. M. \& Glovers, J. S. (1963) Biochem. J. 89, 114-123.

11. Bönner, G. \& Marin-Grez, M. (1981) J. Clin. Chem. Clin. Biochem. 19, 165-168.

12. Scicli, A. G., Carretero, O. A. \& Rabito, S. F. (1983) Adv. Exp. Med. Biol. 156 A, 877-882.

13. Ando, T. \& Shimamoto, K. (1983) Sapporo Med. J. 52, $453-467$.

14. Erdös, E. G. (1970) Bradykinin, Kallidin and Kallikrein. Handbook Exp. Pharmacol. $X X V$, Springer Press, Heidelberg.
15. Erdös, E. G. (1979) Bradykinin, Kallidin and Kallikrein. Handbook Exp. Pharmacol. XXV Suppl., Springer Press, Heidelberg.

16. Vinci, J. M., Zusman, R. M., Izzo Jr., J. R. \& Keiser, H. R. (1979) Circ. Res. 44, 228-237.

17. Talamo, R. C., Haber, E. \& Austen, K. F. (1969) J. Lab. Clin. Med. 74, 816-827.

18. Mashford, M. L. \& Roberts, M. L. (1972) Biochem. Pharmacol. 21, 2727-2735.

19. Geiger, R., Hell, R. \& Fritz, H. (1982) Hoppe-Seylers Z. Physiol. Chem. 363, 527-530.

20. Surovikina, M. S. (1981) Bull. Exp. Biol. Med. 91, 241 243.

21. Cushieri, A. \& Worthington, K. (1976) Br. J. Surg. 63, 210-212.

22. Mersey, J. H., Williams, G. H., Emanuel, R., Dluhy, R. G., Wong, P. Y. \& Moore, T. J. (1979) J. Clin. Endocrinol. Metab. 48, 642-647.

Dr. med. Gerd Bönner Medizinische Klinik Merheim

Universität Köln

Ostmerheimer Str. 200

D-5000 Köln 91 
i

。 